\title{
Assessment of the current possibility of agricultural use of soils in agricultural areas adjacent to the Copper Smelter "Głogów”
}

\author{
Janusz Rosada ${ }^{1}$, Marta Przewocka $^{2}$ \\ ${ }^{1}$ The Institute of Plant Protection - the National Research Institute, The Department of Ecology and Environment Protection; \\ ul. Władysława Wegorka 20,60-318 Poznań; e-mail: j.rosada@iorpib.poznan.pl \\ ${ }^{2}$ The University of Zielona Góra, the Faculty of Civil and Environmental Engineering; ul. Licealna 9, 65-417 Zielona Góra; \\ e-mail:m.przewocka@o2.pl
}

(c) 2015 Authors. This is an open access publication, which can be used, distributed and reproduced in any medium according to the Creative Commons CC-BY 4.0 License requiring that the original work has been properly cited.

Received: December 2014; accepted: July 2015

\begin{abstract}
Summary: The studies were conducted in the years 2012-2014 on agricultural areas affected by the gas and dust emissions of the Copper Smelter "Głogów". The content of five trace elements - copper $(\mathrm{Cu})$, lead $(\mathrm{Pb})$, zinc $(\mathrm{Zn})$, cadium $(\mathrm{Cd})$, arsenic (As) - was determined in soil samples collected on the borders of the protection zone of the smelter by means of the AAS method. Additionally, the collected samples were used to determine the $\mathrm{pH}$ of the analysed soil. The studies showed that the contents of the analysed trace elements in the soil depended on the location of the soil in relation to the sources of the emission of the pollution and were the result of a strong concentration of these elements in a period of intensified emission from the plant. The element which caused the greatest soil pollution was copper. A strong variation in $\mathrm{pH}$ values was observed in the analysed soils (ranging from acid to alkaline reactions). The $\mathrm{pH}$ of most of the soils was $\geq 5.6$. The conducted studies formed the basis for determining the initial isoline of the areas which exceeded the legal standards for soil quality in the discussed area. These studies are an integral complement to existing work on the evaluation of the local variability of soil pollution with heavy metals and arsenic in an area affected by smelter emissions.
\end{abstract}

Keywords: pollution, agricultural environment, copper smelter, soils, heavy metals

\section{INTRODUCTION}

From among various industrial contaminants which can pollute the agricultural environment, heavy metals, representing bioaccumulative trace elements, deserve special attention. Dust emissions from the non-ferrous metals plants can be included in the main anthropogenic factors causing increased heavy metal concentrations in the agricultural environment. Heavy metals contained in the metallurgical dust emitted into the atmosphere may exert a negative impact on all elements of the environment, but the most durable effects can be observed especially in the soil due to the adsorption of numerous metals on mineral and organic colloids. The types and chemical forms of heavy metals occurring in soils affected by the emissions from non-ferrous metals smelters depend on the production process implemented in particular plants. From the ecological point of view, the increased content of heavy metals at the arable and humus horizons of soils is particularly hazardous. The removal of heavy metals from soil is extremely complicated since they constitute a very specific and durable form of pollution. Their deposition in the soil may be extremely persistent and, to a large extent, depends on the type of soil and its physical and chemical characteristics. Hence, there is a need to develop an efficient method for the reclamation of those soils polluted with heavy 
metals in order to avoid the contamination of crops intended for consumption or used as fodder.

As well as metal-bearing dust emissions resulting from smelter processes, gas emissions (sulphur, nitrogen and carbon oxides) and the storage of hazardous waste generated during the processes of production of non-ferrous metals exert an equally negative impact on the environment. The above mentioned hazards are of local nature and concern mainly the areas directly affected by the emissions from the plants.

The gradual shrinkage of areas in Europe on which sustainable farming can be conducted results in the fact that the recovery of certain industrial areas for agricultural purposes has become one of the priorities of the state and local authorities. This refers, in particular, to areas with fertile soils, such as, for instance, the agricultural areas adjoining the Copper Smelter "Głogów". The significant decrease in the current gas and dust emissions from the smelter, owing to the introduction of modern technologies in copper production, combined with the application of efficient methods for the reclamation of soils polluted with trace elements create an opportunity to re-use these areas for purpose of the safe production of plants.

The above mentioned considerations constituted the inspiration to conduct studies whose aim was to:

- determine the impact of the radical reduction in emissions from the Copper Smelter "Głogów" on the content of trace elements (As - arsenic, $\mathrm{Cd}$ - cadmium, $\mathrm{Cu}$ - copper, $\mathrm{Pb}$ - lead and $\mathrm{Zn}$ - zinc) in the soil in the years 2012-2014 against the background of the previous studies on this subject conducted by The Institute of Plant Protection - the National Research Institute of Poznań;

- determine the current usefulness of the analysed soils for agricultural purposes.

\section{THE COPPER SMELTING INDUSTRY IN POLAND AND ITS IMPACT ON THE ENVIRONMENT}

The copper smelting industry plays a significant role in the Polish metallurgical industry. KGHM "Polska Miedź" is the main local producer of copper and its organisational structure comprises two smelting plants: The Copper Smelter "Głogów" and the Copper Smelter Legnica. Both plants are located in agricultural areas and in the vicinity of cities, which increases the risks of environmental hazards resulting from the side effects of the pyro-metallurgical processing of copper ores in these plants.

\section{The impact of the emissions from copper smelters on soil and vegetation}

The specific nature of copper smelting, and in particular the volume and composition of the streams of materials involved in the production process determine the classification of this branch of industry as harmful to the environment. The agricultural lands affected by the impact of the copper plant are characterised by increased levels of zinc, cadmium and arsenic. Strong pollution of agricultural lands with heavy metals may, in extreme cases, lead to irreversible changes in the soil since metals, contrary to organic substances, do not surrender to microbiological decomposition (Kabata-Pendias \& Pendias 1993, Rosada \& Chudziński 1996, Grzesiak et al. 2003, Maciejewska 2003, Rosada 2005).

The increased content of heavy metals in soil poses the threat of their penetration into unconfined and underground waters which constitute sources of drinking water as well water for plants grown on these soils. Metals occurring in soils in potentially mobile forms which can penetrate into the soil profile and move into the soil solution are most accessible to plants (Kabata-Pendias \& Pendias 1993, Maciejewska 2003).

The amount of heavy metals collected from the soil by the root system of plants depends on the degree of concentration of the respective elements in examined soil and on the capacity of the sorptive complex to immobilise them. The sorption capacity of the soil depends on the amount of loam particles, the content of organic substances and the reaction. In soils with a large content of colloidal loam and humus as well with a high $\mathrm{pH}$, metals are bonded by the favourable buffer system of the soil and because of this they are not easily accessible to the plants.

As well as the soil, the direct fall of metal-bearing dust, emitted into the atmosphere, onto the ground plant organs constitutes another source of heavy metals for plants cultivated in the vicinity of smelters. The amount of metals retained in this 
way by the plants depends on the structure of the surface and the type of plant organ on which the dust from the emissions is deposited. The level of pollution is also determined by such factors as the distance between farming areas and the source of the emission, weather conditions, above all, precipitation, as well as the direction, force and frequency of the wind in the area. It is estimated that in areas of increased industrial dust emissions, on average, $70-90 \%$ of the contents of metals in the plants comes from atmospheric sources (Kabata-Pendias \& Pendias 1993, Rosada 1996, Pilc et al. 1999).

Particular species' of plants demonstrate diverse tolerances to specific metals and are characterised by different accumulation characteristics. The studies showed that the distribution of heavy metals in polluted plants is generally advantageous from the point of view of human nutrition. The organs which accumulate nutrients (storage roots, storage stems, storage leaves, fruit and seeds), which form the edible parts of a plant, usually contain fewer metals than roots, leaves and sprouts. It is difficult to determine unambiguously the permissible maximum levels of the contents of various metals from the point of view of the requirements for food and feeding stuff. The tolerance to excessive concentration of these elements in arable crops varies significantly and depends on individual characteristics as well as the frequency and amount of consumption of the polluted products (Kabata-Pendias \& Pendias 1993, Maciejewska 2003).

Metals from anthropogenic sources, in view of the chemical forms in which they are introduced into the environment, demonstrate significantly higher solubility compared to metals of lithogenic origin. In the soils affected by the emission from non-ferrous metals plants, metals occur in the form of oxides, sulphides, sulphates and carbonates (Pacyna 1987, Kabata-Pendias \& Pendias 1993, Ross 1994, Maskall \& Thornton 1998).

Heavy metals introduced into soil with dust undergo gradual redistribution and transformation into the forms characteristic for the properties of a particular soil and the type of metal. In the case of the introduction of excessive amounts of metals into the soil, the natural balance of the soil environment may be disrupted, which significantly increases the risk of the penetration of metals into the food chain of the ecosystem (Kabata-Pendias \& Pendias 1993, Maciejewska 2003).
Soils in the areas affected by the emissions from copper smelters are also significantly polluted by sulphur compounds. The emission of sulphur compounds into the atmosphere constitutes one of the major problems for agricultural lands located within the impact range of smelter plants. All emitted sulphur compounds undergo tropospheric transformation into sulphuric anhydride $\left(\mathrm{SO}_{3}\right)$, which combines with steam or water into sulphuric acid, and in the form of acid rain negatively affects plants and intensifies soil degradation by acidification. The ecological effects of the acidification of soil are connected with unfavourable changes in the chemical composition of plants and the biology of soil, a decrease in the amount of crops and a deterioration in their quality, the contamination of ground water by the elements washed out from the soil, increased mobility of the majority of heavy metals and activation of other toxic elements (Kabata-Pendias \& Pendias 1993, Grzesiak et al. 1997, 2004).

\section{Threats to the agricultural environment located in the vicinity of the Copper Smelter "Głogów"}

Despite the fact that, at present, the Copper Smelter "Głogów" uses modern technologies of copper production which do not diverge from world standards, the plant is still perceived as a significant source of pollution for the ecosystem. The smelter is located in the vicinity of areas characterised by high quality soil on which cereal (mainly wheat), root and tuber crops (sugar beets, potatoes) and industrial plants (rape) are grown. The small distance between the fields and the sources of the emission increases the probability of their pollution. This applies primarily to those crops situated in the most frequent direction of winds in the region (south-westerly and westerly).

Large amounts of dust containing noxious pollutants are produced as a side effect of copper concentrate processing in the Copper Smelter "Głogów". The dust emitted into the atmosphere is a carrier of heavy metals (mainly $\mathrm{Cu}, \mathrm{Pb}, \mathrm{Zn}$ ), and small amounts of cadmium (Cd) and arsenic (As).

In the initial years of the operation of the Plant, the dust emission was very high, which resulted in the significant accumulation of some heavy metals (especially $\mathrm{Cu}$ and $\mathrm{Pb}$ ) in the soil located in its vicinity. In the late seventies and early eighties of 
the $20^{\text {th }}$ century, much less attention was paid to environmental issues than at present. At that time, the economic aspect, that is, the number of tonnes of copper produced, was most important and hence, for instance, in 1980 the emission of $\mathrm{Cu}$ from the Copper Smelter "Głogów" was 160 times higher and lead 260 times higher than at present.

Over the last few decades, as a result of the modernisation of the technology of copper production and also owing to the equipping of all the process units of the smelter with dust extraction units, the level of dust emission has been significantly limited. However, this does not change the fact that heavy metals which penetrated the arable layer of the soils during the period of high emission from the smelter are still present in the soil.

Even twenty five years ago, the agricultural lands located in the neighbourhood of the Copper Smelter "Głogów" were classified as a region of ecological disaster. The amount of gas and metal-bearing dust emitted at that time into the atmosphere exceeded the permissible standards several times over. Clear phytotoxic impact of the emissions from the plant on nearby agricultural lands was observed (Baluk 1985, Baluk et al. 1991, 1992).

In the year 1990, on the basis of the governor of the Legnickie province, a protection zone was established around the Copper Smelter "Głogów". The establishment of the zone was aimed at the elimination of the risk of contamination of the agrocenoses most endangered by the impact of the emissions. The areas situated in the direct vicinity of the plant were excluded from agricultural production and instead sod and poplar trees were planted. At that time the protection zone of the plant covered an area of 2,840 ha.

During the last 25 years, owing to the intensive pro-ecological activities of the plant, the condition of the agricultural environment around the smelter has improved significantly. The modernisation of the copper production technology applied by the smelter as well as the introduction of efficient treatment systems has led to the containment of all the side processes related to copper smelting. The emission of toxic gases and dust containing metals was drastically reduced. Monitoring tests of the soil and plants conducted in this region since the year 2000, have indicated a significant improvement in the ecological security of the local agrocenoses. Above all, the degree of the pollution of crops with heavy metals and arsenic has become significantly lower (Rosada 2003a, 2003b, 2004, 2005, 2007, Rosada \& Grzesiak 2004, 2009, Rosada et al. 2005a).

The emission of sulphur dioxide $\left(\mathrm{SO}_{2}\right)$ into the atmosphere was almost completely eliminated. Thus, the extent of soil acidification decreased significantly. The sulphur dioxide, released in the process of conversion, is presently used in the production of sulphuric acid (Grzesiak et al. 2004).

Since, there is a tendency for acidification in all types of intensely cultivated soil, stabilisation of the $\mathrm{pH}$ by means of systematic liming is of particular importance. This applies especially to those soils with decreased contents of humus and loam particles. Even a very small increase in the acidity of soil increases the risk of the activation of heavy metals and arsenic from the sorptive complex, which may lead to the unnecessary pollution of plants and result in lower crops.

In view of the above, over several years, as well as the constant modernisation of the technology of copper production, the planned pro-ecological activities of the Copper Smelter have involved the co-financing of the liming of the local soils in order to limit the mobility of the accumulated heavy metals. In the years 1988-1999, farmers obtained large amounts of agricultural limestone from the smelter for free, which enabled large-scale liming of the polluted ground. Most soils located within range of the emissions of the plant underwent deacidification at that time. In the year 2000, the Copper Smelter abandoned the free of charge provision of agricultural lime to the farmers, yet from 2002 the farmers could purchase a certain quantity of agricultural lime for lower prices which included state subsidies. The Department of Environment Protection of the Copper Smelter advises the farmers to lime the soil regardless of the subsidies. Numerous users of the agricultural lands follow this advice and lime the grounds systematically. Intensive liming of the soils has contributed to an increase in the $\mathrm{pH}$ in the arable horizon of most of the croplands (Przewocka \& Rosada 2014).

The pro-ecological activities taken throughout the years by the Copper Smelter "Głogów" have contributed to the elimination or significant reduction of the majority of the negative effects of the pyro-metallurgical processing of copper ores in the plant on the environment. In view of the significant improvement of the condition of the 
agrocenoses located in the immediate vicinity of the plant, on December 31, 2005 the Minister of the Environment decided to liquidate the protection zone around the plant. The decision was substantiated by the currently applicable regulations of the Environment Protection Act.

\section{THE SCOPE OF STUDIES CONDUCTED BY IOR-PIB ON THE AGRICULTURAL LANDS LOCATED IN THE VICINITY OF THE COPPER SMELTER “GLOGÓW”}

The Institute of Plant Protection - the National Research Institute (IOR-PIB) in Poznań has cooperated with the Copper Smelter "Głogów" for a number of years in respect of the analysis of the effects of industrial pollution on the environment and the identification of efficient methods of reclaiming agricultural lands. The agricultural lands subjected to the analysis conducted by IORPIB covered 6,600 ha and included the protection zone of the plant (at present the former protection zone) as well as the areas located on the left and right bank of the Odra River.

On the basis of the long-term results, a vast database concerning the pollution of soil and plants in the area affected by the plant during the periods of strong gas and dust emission, as well as after its limitation, was developed. Owing to the conducted studies the paths of penetration of heavy metals into the arable plants were identified as well as their distribution in vegetative (roots, stems and leaves) and generative (fruit, seeds) parts of the cultivated plants (Rosada \& Chudziński 1997, Rosada 2006, Rosada \& Grzesiak 2007).

In order to develop efficient methods of reclaiming those lands affected by the emissions from the plant, detailed studies on the physical and chemical properties of the analysed soils (particle size distribution, the contents of organic carbon and total nitrogen, the $\mathrm{pH}$ in $1 \mathrm{M} \mathrm{KCl}$ ) combined with the determination of the forms of $\mathrm{Cu}$, $\mathrm{Pb}, \mathrm{Zn}, \mathrm{Cd}$ and As occurring in the solid phase of the soils was conducted by means of the sequential extraction method (Rosada 2008).

The determination of the particle size distribution, the contents of the organic matter, the sorptive capacity and the $\mathrm{pH}$ all created the possibility of a fairly precise prediction of the probability of the activation of metals from the sorption complex and identification of the threat of their absorption by the plants (Rosada 2006).

The studies showed that the forms of the analysed elements determined by means of the method of sequential extraction in the solid phase of soils subjected to $\mathrm{pH}$ stabilisation largely depended on the type of elements, i.e. their chemical properties and the characteristics of the analysed soil. The total contents of the analysed elements, calculated on the basis of seven fractions by means of the Zeien and Brümmer method was comparable, when their total contents were determined independently by means of nitric acid mineralisation (Zeien \& Brümmer 1989, 1991, Spychalski \& Rosada 2004, 2005, Rosada et al. 2005b, Spychalski et al. 2007, Rosada 2008).

The application character of the described studies consists of the determination of the optimal dose of a chemical stabiliser guaranteeing the limitation of the mobility of heavy metals and arsenic in the soils affected by the emissions from the Copper Smelter "Głogów". The sequential extraction of the studied trace elements in the soil, subjected to the process of chemical $\mathrm{pH}$ stabilisation showed a significant share of $\mathrm{Cu}, \mathrm{Pb}, \mathrm{Zn}$ and As in less mobile fractions, which is an extremely positive phenomenon from an ecological point of view. The application of the determined dose of the chemical stabiliser by the users of the local agricultural lands limits the absorption of the analysed elements from the sorptive complex of the soil by the root system of the arable plants, which in turn increases the safety of cultivation of these plants on the polluted soils (Rosada et al. 2005c).

\section{METHODOLOGY OF THE STUDIES}

The studies presented in this paper were conducted in the years 2012-2014 in the areas affected by the gas and dust emission of the Copper Smelter "Głogów".

The analysed material included soil samples collected for the purpose of the determination of the contents of five trace elements $(\mathrm{Cu}, \mathrm{Pb}, \mathrm{Zn}, \mathrm{Cd}$, As) as well as the $\mathrm{pH}$. The samples were collected annually from 20 permanent research points (surfaces) located on the peripheries of the former protection zone of the plant (Fig. 1). 


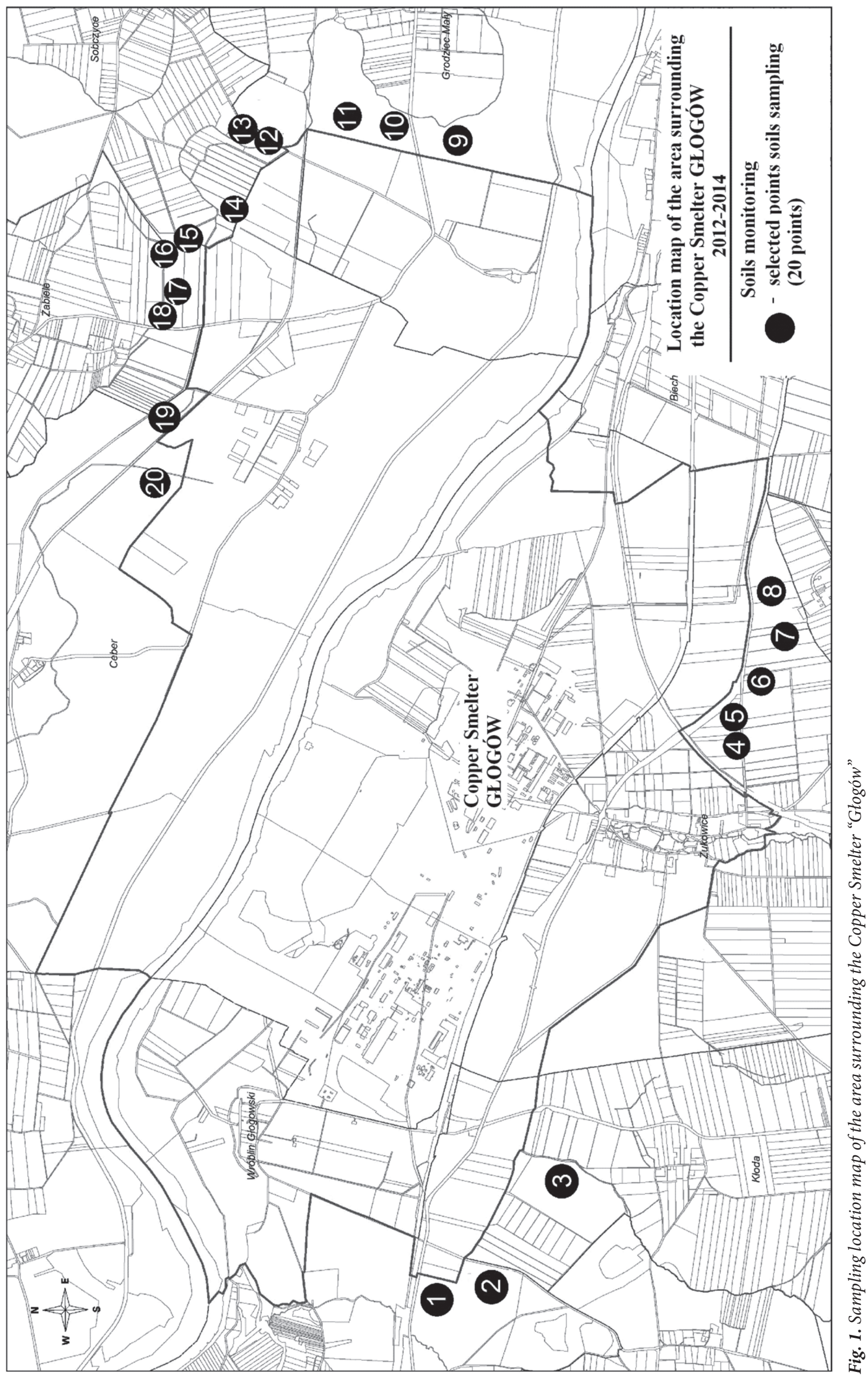


The soil samples for analysis were collected in spring from the arable-humus horizon $(0-30 \mathrm{~cm})$ with the aid of a specialist mechanical drill. The locations of the soil collection points were determined by means of GPS. From each analysed point (research surface) 30 individual samples were collected, which were subsequently mixed and treated as an average sample.

Prior to analysis, the soil samples were dried at room temperature, then they were ground in a porcelain mortar and screened through a plastic sieve with $2 \mathrm{~mm}$ meshes in order to separate the skeleton and fine earth particles. After screening, each sample was mixed in order to obtain a high degree of homogeneity.

The homogenous material was ground in a Pulverisette 7 planetary micro mill with agate balls for the purpose of more precise soil pulverisation.

Subsequently, the samples prepared in this way were subjected to mineralisation. For this purpose $0.5 \mathrm{~g}$ of the studied soil was placed in the mineralisation vessel, and macerated for $30 \mathrm{~min}$, with $10 \mathrm{~cm}^{3}$ of nitric acid $(\mathrm{V})$. After the expiry of this time the vessel containing the sample was placed in a microwave oven and further mineralised, using an appropriate program. "Blank tests" were also performed. The mineralised material was transferred quantitatively to $50 \mathrm{~cm}^{3}$ volumetric flasks. The complements were carried out with deionised water.

The content of the five studied elements in the soil samples were determined by means of the AAS method. The equipment used for the purpose of determination was fully computerised, i.e., it performed several independent measurements automatically and the results were presented as arithmetic means. Arsenic was determined using the hydride generation technique.
The results of the determination of the content of the studied elements in the analysed samples have been presented in the tables below, taking into account the measurement uncertainty (the proper result of determination \pm the measurement uncertainty expressed in $\mathrm{mg} / \mathrm{kg}$ of dry mass).

The determination of the studied elements was performed in the Environmental Analysis Laboratory of the Institute of Plant Protection - the National Research Institute in Poznań. The Laboratory has been granted the Accreditation Certificate for a Testing Laboratory no. AB 1281 of the Polish Center for Accreditation.

\section{STUDY RESULTS AND DISCUSSION}

Past studies conducted on the agricultural lands located in the vicinity of the Copper Smelter "Głogów" showed that the soils can be classified into four agronomic categories: very light, light, medium and heavy soils. The soils are distinguished by their high diversification from the point of view of their texture. In accordance with the division included in the Polish Standard PNR-04033, the studied soils belong to three textural groups (sand, silt, clay). Dust soil located on the left bank of the Odra River is the prevalent formation, and on the other hand, less numerous sand and clay formations prevail on the right bank of the Odra River. The content of organic carbon ranges between $0.57 \%$ and $2.11 \%$ and nitrogen between $0.07 \%$ and $0.23 \%$ (Rosada 2008).

The results of the determination of the total content of heavy metals and arsenic in the soil studied in the years 2012-2014, as well as the $\mathrm{pH}$ values are presented in Tables 1-3.

Table 1

The content of the studied trace elements and the $\mathrm{pH}$ of the analysed soil during the first year of studies

\begin{tabular}{|c|c|c|c|c|c|c|}
\hline \multicolumn{2}{|c|}{$\begin{array}{c}\text { Soil } \\
\text { collection } \\
\text { point }\end{array}$} & \multirow{2}{*}{$\mathbf{p H}$} & \multicolumn{7}{|c|}{ Studied elements [mg/kg d.m.] } \\
\cline { 3 - 7 } & & $\mathbf{C u}$ & $\mathbf{P b}$ & $\mathbf{Z n}$ & Cd & As \\
\hline 1 & 5.9 & $90.04 \pm 10.00$ & $37.46 \pm 8.40$ & $18.81 \pm 3.00$ & $0.13 \pm 0.02$ & $3.85 \pm 1.00$ \\
\hline 2 & 7.3 & $121.31 \pm 14.00$ & $50.66 \pm 11.00$ & $29.60 \pm 4.70$ & $0.19 \pm 0.03$ & $5.69 \pm 1.50$ \\
\hline 3 & 6.4 & $35.47 \pm 15.00$ & $55.25 \pm 12.00$ & $25.70 \pm 4.10$ & $0.19 \pm 0.03$ & $5.71 \pm 1.50$ \\
\hline 4 & 7.0 & $159.71 \pm 18.00$ & $61.10 \pm 14.00$ & $42.14 \pm 6.80$ & $0.28 \pm 0.05$ & $6.19 \pm 1.60$ \\
\hline
\end{tabular}


Table 1 cont.

\begin{tabular}{|c|c|c|c|c|c|c|}
\hline \multicolumn{2}{|c}{$\begin{array}{c}\text { Soil } \\
\text { collection } \\
\text { point }\end{array}$} & $\mathbf{p H}$ & \multicolumn{5}{|c|}{ Studied elements [mg/kg d.m.] } \\
\cline { 3 - 7 } & & $\mathbf{C u}$ & $\mathbf{P b}$ & Zn & Cd & As \\
\hline 5 & 7.3 & $150.97 \pm 10.00$ & $36.27 \pm 8.10$ & $30.91 \pm 5.00$ & $0.23 \pm 0.04$ & $5.73 \pm 1.50$ \\
\hline 6 & 6.3 & $144.42 \pm 16.00$ & $57.72 \pm 13.00$ & $36.93 \pm 5.90$ & $0.28 \pm 0.05$ & $7.42 \pm 2.00$ \\
\hline 7 & 6.2 & $165.55 \pm 19.00$ & $61.71 \pm 14.00$ & $43.43 \pm 7.00$ & $0.34 \pm 0.06$ & $8.91 \pm 2.40$ \\
\hline 8 & 7.2 & $156.75 \pm 18.00$ & $56.55 \pm 13.00$ & $39.37 \pm 6.30$ & $0.30 \pm 0.05$ & $9.88 \pm 2.60$ \\
\hline 9 & 6.3 & $139.08 \pm 16.00$ & $51.51 \pm 12.00$ & $36.23 \pm 5.80$ & $0.21 \pm 0.04$ & $6.15 \pm 1.60$ \\
\hline 10 & 6.1 & $109.74 \pm 12.00$ & $44.46 \pm 10.00$ & $70.19 \pm 11.00$ & $0.26 \pm 0.05$ & $10.61 \pm 2.80$ \\
\hline 11 & 6.5 & $96.91 \pm 11.00$ & $45.03 \pm 10.00$ & $58.91 \pm 9.40$ & $0.30 \pm 0.06$ & $10.68 \pm 2.80$ \\
\hline 12 & 5.9 & $120.28 \pm 14.00$ & $48.31 \pm 11.00$ & $48.16 \pm 7.70$ & $0.18 \pm 0.03$ & $5.48 \pm 1.50$ \\
\hline 13 & 6.1 & $105.65 \pm 12.00$ & $43.96 \pm 10.00$ & $63.21 \pm 10.00$ & $0.19 \pm 0.04$ & $7.19 \pm 1.90$ \\
\hline 14 & 6.1 & $145.44 \pm 16.00$ & $57.35 \pm 13.00$ & $69.57 \pm 11.00$ & $0.25 \pm 0.05$ & $7.80 \pm 2.10$ \\
\hline 15 & 5.9 & $165.71 \pm 19.00$ & $80.07 \pm 18.00$ & $83.55 \pm 13.00$ & $0.25 \pm 0.05$ & $8.53 \pm 2.30$ \\
\hline 16 & 6.3 & $151.17 \pm 17.00$ & $65.82 \pm 15.00$ & $79.11 \pm 13.00$ & $0.27 \pm 0.05$ & $6.70 \pm 1.80$ \\
\hline 17 & 6.8 & $187.24 \pm 21.00$ & $76.77 \pm 17.00$ & $89.44 \pm 14.00$ & $0.33 \pm 0.06$ & $9.56 \pm 2.50$ \\
\hline 18 & 6.1 & $141.62 \pm 16.00$ & $55.03 \pm 12.00$ & $44.99 \pm 7.20$ & $0.22 \pm 0.04$ & $6.77 \pm 1.80$ \\
\hline 19 & 5.8 & $149.59 \pm 17.00$ & $55.23 \pm 12.00$ & $46.33 \pm 7.40$ & $0.22 \pm 0.04$ & $6.36 \pm 1.70$ \\
\hline 20 & 5.6 & $118.92 \pm 13.00$ & $46.72 \pm 10.00$ & $36.49 \pm 5.90$ & $0.21 \pm 0.04$ & $6.81 \pm 1.80$ \\
\hline
\end{tabular}

The contents of trace elements are presented as arithmetic means of several independent measurements. Medium values were calculated automatically by measuring equipment (AAS).

Table 2

The content of the studied trace elements and the $\mathrm{pH}$ of the soil analysed during the second year of studies

\begin{tabular}{|c|c|c|c|c|c|c|}
\hline \multicolumn{2}{|c}{$\begin{array}{c}\text { Soil } \\
\text { collection } \\
\text { point }\end{array}$} & \multirow{2}{*}{$\mathbf{p H}$} & \multicolumn{5}{|c|}{ Studied elements [mg/kg d.m.] } \\
\cline { 3 - 7 } & & $\mathbf{C u}$ & $\mathbf{P b}$ & $\mathbf{Z n}$ & Cd & As \\
\hline 1 & 6.7 & $115.00 \pm 3.00$ & $38.20 \pm 8.60$ & $24.20 \pm 3.90$ & $0.21 \pm 0.04$ & $5.40 \pm 1.40$ \\
\hline 2 & 7.1 & $141.00 \pm 6.00$ & $52.00 \pm 12.00$ & $30.70 \pm 4.90$ & $0.30 \pm 0.05$ & $5.40 \pm 1.40$ \\
\hline 3 & 7.3 & $156.00 \pm 18.00$ & $66.00 \pm 15.00$ & $28.80 \pm 4.60$ & $0.22 \pm 0.04$ & $6.60 \pm 1.70$ \\
\hline 4 & 6.6 & $157.00 \pm 18.00$ & $55.00 \pm 12.00$ & $46.00 \pm 7.40$ & $0.34 \pm 0.06$ & $4.90 \pm 1.30$ \\
\hline 5 & 7.2 & $178.00 \pm 20.00$ & $62.00 \pm 14.00$ & $45.70 \pm 7.30$ & $0.32 \pm 0.06$ & $6.20 \pm 1.60$ \\
\hline 6 & 7.1 & $157.00 \pm 18.00$ & $59.00 \pm 13.00$ & $41.00 \pm 6.60$ & $0.38 \pm 0.07$ & $7.30 \pm 1.90$ \\
\hline 7 & 5.8 & $148.00 \pm 17.00$ & $59.00 \pm 13.00$ & $39.30 \pm 6.30$ & $0.39 \pm 0.07$ & $7.20 \pm 1.90$ \\
\hline 8 & 6.2 & $139.00 \pm 16.00$ & $51.00 \pm 11.00$ & $34.40 \pm 5.50$ & $0.26 \pm 0.05$ & $6.50 \pm 1.70$ \\
\hline 9 & 7.3 & $107.00 \pm 12.00$ & $39.10 \pm 8.80$ & $34.20 \pm 5.50$ & $0.20 \pm 0.04$ & $7.10 \pm 1.90$ \\
\hline 10 & 6.3 & $128.00 \pm 14.00$ & $52.00 \pm 12.00$ & $77.00 \pm 12.00$ & $0.31 \pm 0.06$ & $9.90 \pm 2.60$ \\
\hline 11 & 6.4 & $97.00 \pm 11.00$ & $41.90 \pm 9.40$ & $47.50 \pm 7.60$ & $0.24 \pm 0.05$ & $7.70 \pm 2.10$ \\
\hline
\end{tabular}


Table 2 cont.

\begin{tabular}{|l|c|c|c|c|c|c|}
\hline 12 & 6.2 & $107.00 \pm 12.00$ & $44.00 \pm 10.00$ & $43.80 \pm 7.00$ & $0.23 \pm 0.04$ & $5.20 \pm 1.40$ \\
\hline 13 & 6.0 & $93.00 \pm 10.00$ & $45.00 \pm 10.00$ & $59.40 \pm 9.50$ & $0.29 \pm 0.05$ & $6.50 \pm 1.70$ \\
\hline 14 & 5.5 & $125.00 \pm 14.00$ & $53.00 \pm 12.00$ & $63.00 \pm 10.00$ & $0.24 \pm 0.04$ & $7.90 \pm 2.10$ \\
\hline 15 & 5.5 & $92.00 \pm 10.00$ & $44.00 \pm 10.00$ & $28.70 \pm 4.60$ & $0.16 \pm 0.03$ & $6.80 \pm 1.80$ \\
\hline 16 & 6.2 & $124.00 \pm 14.00$ & $54.00 \pm 12.00$ & $62.00 \pm 10.00$ & $0.29 \pm 0.05$ & $8.10 \pm 2.20$ \\
\hline 17 & 7.2 & $144.00 \pm 16.00$ & $60.00 \pm 13.00$ & $55.30 \pm 8.90$ & $0.31 \pm 0.06$ & $9.50 \pm 2.50$ \\
\hline 18 & 6.3 & $113.00 \pm 13.00$ & $51.00 \pm 11.00$ & $33.40 \pm 5.40$ & $0.21 \pm 0.04$ & $5.80 \pm 1.50$ \\
\hline 19 & 6.0 & $140.00 \pm 16.00$ & $55.00 \pm 12.00$ & $33.20 \pm 5.30$ & $0.20 \pm 0.04$ & $7.10 \pm 1.90$ \\
\hline 20 & 6.4 & $168.00 \pm 19.00$ & $70.00 \pm 16.00$ & $46.60 \pm 7.50$ & $0.25 \pm 0.05$ & $9.00 \pm 2.40$ \\
\hline
\end{tabular}

The contents of trace elements are presented as arithmetic means of several independent measurements. Medium values were calculated automatically by measuring equipment (AAS).

Table 3

The content of the studied trace elements and the pH of the soil analysed during the third year of studies

\begin{tabular}{|c|c|c|c|c|c|c|}
\hline \multicolumn{7}{|c|}{2014} \\
\hline \multirow{2}{*}{$\begin{array}{c}\text { Soil } \\
\text { collection } \\
\text { point }\end{array}$} & \multirow{2}{*}{$\mathrm{pH}$} & \multicolumn{5}{|c|}{ Studied elements [mg/kg d.m.] } \\
\hline & & $\mathrm{Cu}$ & $\mathbf{P b}$ & Zn & Cd & As \\
\hline 1 & 6.7 & $110.00 \pm 12.00$ & $39.80 \pm 8.90$ & $20.00 \pm 3.20$ & $0.11 \pm 0.02$ & $5.70 \pm 1.50$ \\
\hline 2 & 6.1 & $122.00 \pm 14.00$ & $41.10 \pm 9.20$ & $29.80 \pm 4.80$ & $0.17 \pm 0.03$ & $6.00 \pm 1.60$ \\
\hline 3 & 5.2 & $131.00 \pm 15.00$ & $51.00 \pm 12.00$ & $21.70 \pm 3.50$ & $0.15 \pm 0.03$ & $7.10 \pm 1.90$ \\
\hline 4 & 6.7 & $167.00 \pm 19.00$ & $59.00 \pm 13.000$ & $45.30 \pm 7.30$ & $0.23 \pm 0.04$ & $6.90 \pm 1.80$ \\
\hline 5 & 7.1 & $184.00 \pm 21.00$ & $68.00 \pm 15.00$ & $44.10 \pm 7.10$ & $0.26 \pm 0.05$ & $7.50 \pm 2.00$ \\
\hline 6 & 7.3 & $154.00 \pm 17.00$ & $55.00 \pm 12.00$ & $43.80 \pm 7.00$ & $0.26 \pm 0.05$ & $9.20 \pm 2.40$ \\
\hline 7 & 6.4 & $135.00 \pm 15.00$ & $52.00 \pm 12.00$ & $36.40 \pm 5.80$ & $0.23 \pm 0.04$ & $7.50 \pm 2.00$ \\
\hline 8 & 6.5 & $168.00 \pm 19.00$ & $61.00 \pm 14.00$ & $39.40 \pm 6.30$ & $0.31 \pm 0.06$ & $7.80 \pm 2.10$ \\
\hline 9 & 7.2 & $151.00 \pm 17.00$ & $49.00 \pm 11.00$ & $58.60 \pm 9.40$ & $0.22 \pm 0.04$ & $13.50 \pm 3.60$ \\
\hline 10 & 6.4 & $131.00 \pm 15.00$ & $46.00 \pm 10.00$ & $61.80 \pm 9.90$ & $0.22 \pm 0.04$ & $14.00 \pm 3.70$ \\
\hline 11 & 6.4 & $120.00 \pm 14.00$ & $41.40 \pm 9.30$ & $66.00 \pm 11.00$ & $0.19 \pm 0.04$ & $17.40 \pm 4.60$ \\
\hline 12 & 5.3 & $119.00 \pm 13.00$ & $47.00 \pm 11.00$ & $71.00 \pm 11.00$ & $0.22 \pm 0.04$ & $14.60 \pm 3.90$ \\
\hline 13 & 5.7 & $150.00 \pm 17.00$ & $63.00 \pm 14.00$ & $64.00 \pm 10.00$ & $0.24 \pm 0.04$ & $11.20 \pm 3.00$ \\
\hline 14 & 5.3 & $109.00 \pm 12.00$ & $49.00 \pm 11.00$ & $56.00 \pm 9.00$ & $0.19 \pm 0.04$ & $7.60 \pm 2.00$ \\
\hline 15 & 5.8 & $139.00 \pm 16.00$ & $50.00 \pm 11.00$ & $68.00 \pm 11.00$ & $0.23 \pm 0.04$ & $12.40 \pm 3.30$ \\
\hline 16 & 6.2 & $129.00 \pm 15.00$ & $49.00 \pm 11.00$ & $46.70 \pm 7.50$ & $0.20 \pm 0.04$ & $12.10 \pm 3.20$ \\
\hline 17 & 6.7 & $145.00 \pm 16.00$ & $55.00 \pm 12.00$ & $60.00 \pm 9.60$ & $0.30 \pm 0.06$ & $11.50 \pm 3.10$ \\
\hline 18 & 6.3 & $165.00 \pm 18.00$ & $71.00 \pm 16.00$ & $61.70 \pm 9.90$ & $0.32 \pm 0.06$ & $16.10 \pm 4.30$ \\
\hline 19 & 5.0 & $128.00 \pm 14.00$ & $58.00 \pm 13.00$ & $36.20 \pm 5.80$ & $0.21 \pm 0.04$ & $8.30 \pm 2.20$ \\
\hline 20 & 6.7 & $158.00 \pm 18.00$ & $58.00 \pm 13.00$ & $34.00 \pm 5.40$ & $0.19 \pm 0.06$ & $9.30 \pm 2.50$ \\
\hline
\end{tabular}

The contents of trace elements are presented as arithmetic means of several independent measurements. Medium values were calculated automatically by measuring equipment (AAS). 
The studies showed significant variations in the reactions of analysed soils $(\mathrm{pH} \mathrm{5.0-7.3).} \mathrm{The}$ $\mathrm{pH}$ value of the majority of soils was $\geq 5.6$. In the year 2012, soils with a slightly acid reaction constituted $75 \%$, neutral reaction $-15 \%$ and alkaline reaction $-10 \%$ of all the analysed samples. The reactions of the soils in the year 2013 were as follow: acid reaction $-10 \%$, slightly acid reaction $-50 \%$, neutral reaction $-30 \%$ and alkaline reaction $-10 \%$ of the studied samples. On the other hand, in the year 2014, soils with an acid reaction constituted $20 \%$, slightly acid reaction $-45 \%$, neutral reaction $30 \%$ and alkaline reaction only $5 \%$ of the studied samples.

The conducted studies indicated the prevalence of soils with slightly acid and acid reactions. The gradual decrease in the $\mathrm{pH}$ of the soils located in the immediate vicinity of the Copper Smelter "Głogów" is not the result of the emission of $\mathrm{SO}_{2}$ to the atmosphere since the current gas emissions from the plant have been limited to the minimum. The increase in the soil acidity is rather related to the intensive farming in this area. It has to be remembered that liming is not a one-time activity, which solves the problem of the $\mathrm{pH}$ of the soil on a permanent basis. It has to be repeated systematically, since in all types of intensively cultivated soils, there is a tendency for a slow and gradual increase in the acidity of the soil solution. This refers in particular to soils with lower contents of humus and loam. For the purpose of appropriate monitoring, systematic control of the reaction of the soils and the level of heavy metals contained in them is necessary.

An increase in the acidification of soil is also indirectly related to the abandonment of the financing of the liming processes by the Copper Smelter "Głogów" in 2000. The intensification of soil liming in the region by the local farmers will certainly contribute to an increase in the share of soils with neutral and alkaline reaction. An increase in the $\mathrm{pH}$ of soil improves its chemical and physical properties and decreases the risk of penetration of the accumulated toxic elements into underground waters and the food chain. In the cases of soils with an alkaline or neutral reaction, the risk of the activation of metals is minimised as a result of their bonding in the sorptive complex (they do not move from the solid phase of the soil to the soil solution).

Stabilisation of the soil reaction resulting from the liming process, has been confirmed by the studies conducted in this region by Rosada (2008) in the years 2002-2006. The studies showed that as a consequence of liming, the share of soils with alkaline, neutral and slightly acid reactions was $88 \%$, and acid and strongly acid soils constituted only $12 \%$.

Analysis of the results obtained in the years 2012-2014, concerning the contents of four of the studied elements: $\mathrm{Pb}, \mathrm{Zn}, \mathrm{Cd}$ and As in the soils, showed that none of them exceeded permissible standards specified by the requirements of the Regulation of the Minister of Environment of September $9^{\text {th }}, 2002$ (Journal of Laws, 2002, No. 165 , item 1359) on soil quality standards and land quality standards.

The results of studies on the content of $\mathrm{Cu}$ in the analysed soil showed, however, that the concentration of this element exceeded permissible standards ( $>150 \mathrm{mg} / \mathrm{kg} \mathrm{d.m}$.$) - the Regulation of the Minister$ of Environment of September $9^{\text {th }}, 2002$.

In 2012 the permissible content of $\mathrm{Cu}$ in the soil was observed in seven research points: $4,5,7$, $8,15,16$, and 17 , in 2013 , in five points: $3,4,5,6$ and 20 and in the last year of the studies in seven points: 4, 5, 6, 8, 9, 18 and 20. The content of $\mathrm{Cu}$ in soil samples in which the permissible standard was exceeded ranged from $151 \pm 17 \mathrm{mg} / \mathrm{kg}$ d.m. to $187.24 \pm 21 \mathrm{mg} / \mathrm{kg}$ d.m.

The contents of $\mathrm{Cu}$ exceeding the standard, observed in some studies points may be the result of the unfavourable impact of the wind in this region, which carries the emitted metallurgical dust. In view of the frequency of the wind, the pollution of soil is higher in the south-east and east directions.

The presented studies on $\mathrm{pH}$ determination and the content of selected heavy metals and arsenic in the surface layer of soils located in the immediate vicinity of the Copper Smelter "Głogów" constitute the basis for the determination of initial isoline of the areas where the soil quality standards are exceeded. Beyond this isoline the cultivation of plants for consumption purposes and for feedstuff is absolutely safe.

The studies conducted so far on the agricultural lands covered mainly lands located within the former protection zone and lands adjacent to the zone on the left and right banks of the Odra River. Thus, a comprehensive database was created, which constitutes a starting point for the development of more efficient methods of reclamation 
and monitoring of the lands in the immediate neighbourhood of the plant. The present studies will constitute an integral complement to the work performed so far and will allow for the analysis of the local variability of pollution of the soil with heavy metals and arsenic.

Analysis of the obtained results which indicate that the permissible content of $\mathrm{Cu}$ in the analysed soil is exceeded applies mainly to those points located at the border of the former protection zone. The observed pollution is the result of strong accumulation of the analysed elements in the soil environment during the initial phase of the operation of the plant (the period of intensive emission of metal-bearing dust). The volume of the current emission of the smelter does not exert a significant impact on changes in the level of pollution of the arable horizon of the studied soils (Rosada 2008).

\section{CONCLUSIONS}

1. The content of the analysed heavy metals $(\mathrm{Cu}$, $\mathrm{Pb}, \mathrm{Zn}, \mathrm{Cd}$ ) and arsenic (As) in the soils affected by the emission from the Copper Smelter "Głogów" depends on the location of these soils in relation to the sources of the pollution and are a result of strong accumulation of the studied elements during the period of intensive emissions from the plant. The specific character of the metallurgical activity in the initial years of the smelter's existence became a reliable indicator of the level of anthropogenic impact of the agricultural environment in this region.

2. Copper, to the greatest extent, contributes to the pollution of soil affected by the emissions from the Copper Smelter "Głogów". The content of the remaining elements $(\mathrm{Pb}, \mathrm{Zn}, \mathrm{Cd}$ and As) in the soil is much smaller and within limits established by the standards.

3. The determined content of heavy metals and arsenic in the studied soils contributed to the delimitation of initial isoline of the area on which the soil quality standards are exceeded. Beyond this isoline the cultivation of plants for consumption purposes and for feedstuff should be absolutely safe.

4. The conducted studies showed significant variations in the $\mathrm{pH}$ values in the analysed samples of soil. In most cases, the reaction of the soil was $\mathrm{pH} \geq 5.6$, which may be related to the inappropriately conducted agricultural operations, in particular, irregular soil liming, resulting from the increasing prices of agricultural limestone.

5. Climactic factors, especially wind frequency and force in this region, as well the method of use of the lands exert a significant impact on the content of heavy metals in the soils.

\section{REFERENCES}

Baluk A., 1985. Oddziaływanie emisji Huty Miedzi „Głogów” na kultury rolne. Prace Naukowe Instytutu Ochrony Roślin, 27, 2, 51-91.

Baluk A., Chudziński B. \& Dec J., 1991. Skażenie gleb metalami ciężkimi wokół Huty Miedzi „Głogów” i wynikająca stąd fitotoksyczność. Substancje toksyczne w środowisku, ART Olsztyn, 1, 7-10.

Baluk A., Chudziński B. \& Grala B., 1992. Skażenie płodów rolnych metalami ciężkimi w rejonie oddziaływania Huty Miedzi „Głogów”. Substancje toksyczne w środowisku, ART Olsztyn, 2, 28-32.

Grzesiak P., Schroeder G. \& Hopke W., 1997. Degradation of the natural environment resulting from the presence of Sulphur compounds in the atmosphere. Polish Journal of Environmental Studies, 4, 45-48.

Grzesiak J., Grzesiak P. \& Rosada J., 2003. Charakterystyka pierwiastków emitowanych do atmosfery w procesie produkcji miedzi. [in:] Schroeder G. (red.), Chemiczne aspekty badań środowiska. T. 1, Uniwersytet im. Adama Mickiewicza, Poznań, 59-96.

Grzesiak J., Grzesiak P. \& Rosada J., 2004. Charakterystyka zanieczyszczeń gazowych emitowanych do atmosfery w procesie produkcji kwasu siarkowego. [in:] Schroeder G. (red.), Chemiczne aspekty badań środowiska. T. 2, Uniwersytet im. Adama Mickiewicza, Poznań, 105-114.

Kabata-Pendias A. \& Pendias H., 1993. Biogeochemia pierwiastków śladowych. PWN, Warszawa.

Maciejewska A., 2003. Problematyka rekultywacji gleb zanieczyszczonych metalami ciężkimi w świetle literatury. [in:] Gworek B. \& Misiak J. (red.), Obieg pierwiastków w przyrodzie: monografia. T. 2, Dział Wydawnictw IOŚ, Warszawa, 539-550.

Maskall J.E. \& Thornton I., 1998. Chemical partitioning of heavy metals in soils, clays and rocks at historical lead smelting sites. Water, Air, \& Soil Pollution, 108, 3/4, 391-409.

Pacyna J.M., 1987. Atmospheric emissions of arsenic, cadmium, lead and mercury from high temperature processes in power generation and industry. [in:] Hutchinson T.C. \& Mecma K.M. (eds), Lead, Mercury, Cadmium and Arsenic in the Environment, Scope 31, John Wiley, New York, 69-87.

Pilc L., Rosada J. \& Siepak J., 1999. The Influence of Dust Emission from the "Głogów" Copper Foundry on Heavy Metal Concentrations in Agrocenoses. Polish Journal of Environmental Studies, 8, 2, 111-114. 
Przewocka M. \& Rosada J., 2014. Ocena stopnia zanieczyszczeń gleb na pograniczu byłej strefy ochronnej Huty Miedzi „Głogów”. Zeszyty Naukowe Uniwersytetu Zielonogórskiego. Inżynieria Środowiska, 154, 34, 45-54.

Rosada J., 1996. Przyczyny zanieczyszczenia roślin metalami ciężkimi w rejonie oddziaływania Huty Miedzi „Głogów" - skażone powietrze czy gleba? Progress in Plant Protection/Postępy w Ochronie Roślin, 36, 2, 351-353.

Rosada J., 2003a. Influence of Eco-friendly Activities of Copper Foundry „Głogów” on Condition of Agricultural Environment. [in:] Górecki H., Dobrzański Z. \& Kafarski P. (eds), Chemicals in Sustainable Agriculture, Chemistry for Agriculture, Czech-Pol Trade, Prague - Brussels, 4, 426-429.

Rosada J., 2003b. Aktualny stan środowiska rolniczego w rejonie oddziaływania emisji gazowych i pyłowych Huty Miedzi „Głogów”. [in:] Schroeder G. (red.), Chemiczne aspekty badań środowiska. T. 1, Uniwersytet im. Adama Mickiewicza, Poznań, 145-156.

Rosada J., 2004. Positive changes in agricultural environment as a result of reduction of industrial emissions. [in:] Górecki H., Dobrzański Z. \& Kafarski P. (eds), New Agrochemicals and Their Safe Use for Health and Environment Chemistry for Agriculture, Czech-Pol Trade, Prague - Brussels, 5, 704-707.

Rosada J., 2005. Concentration of heavy metals $(\mathrm{Cu}, \mathrm{Pb}, \mathrm{Zn}$, $\mathrm{Cd}$ ) and arsenic (As) in soils and plants in agricultural areas threatened by emissions from non-ferrous metallurgy. Polish Journal of Chemical Technology, 7, 2, 50-53.

Rosada J., 2006. Factors Influencing the Uptake of Heavy Metals by Crops Plants in the Region of Industrial Emissions. [in:] Górecki H., Dobrzański Z., Kafarski P. (eds), Chemistry and Biochemistry in the Agricultural Production, Environment Protection, Human and Animal Health, Chemistry for Agriculture, Czech-Pol Trade, Prague - Brussels, 7, 589-591.

Rosada J., 2007. Ekologiczne aspekty wykorzystania obszarów objętych oddziaływaniem emisji hut miedzi do upraw rolniczych. Progress in Plant Protection/Postępy w Ochronie Roślin, 47, 1, 119-127.

Rosada J., 2008. Stan środowiska rolniczego w rejonie oddziaływania emisji Huty Miedzi „Głogów”. Rozprawy Naukowe Instytutu Ochrony Roślin - Państwowego Instytutu Badawczego, 19, Wydawnictwo Instytutu Ochrony Roślin Państwowego Instytutu Badawczego, Poznań.

Rosada J. \& Chudziński B., 1996. Copper and Lead - the Main Reasons for Plants Pollution in the Emission Region of Copper Foundry "Głogów". Biological Bulletin of Poznań, 33, 53-54.

Rosada J. \& Chudziński B., 1997. The potential pathways of plants contamination in the emission region of Copper Foundry "Głogów. [in:] INRA (eds), Contaminated Soils, $3 r d$ International Conference on Biogeochemistry of Trace Elements. 15-19 May 1995, Paris, 525 pp. [plus CD with authors' text $084 \mathrm{PDF}]$.

Rosada J. \& Grzesiak J., 2003. Basic Characteristics of Soils in the Emission Region of Copper Foundry "Głogów". [in:] Górecki H., Dobrzański Z., Kafarski P. (eds), Chemicals in Sustainable Agriculture, Chemistry for Agriculture, Czech-Pol Trade, Prague - Brussels, 4, 430-433.

Rosada J. \& Grzesiak J., 2004. Condition of agrocenoses in the protective zone and external belt threatened by emissions of Copper Foundry "Głogów". [in:] Górecki H.,
Dobrzański Z. \& Kafarski P. (eds), New Agrochemicals and Their Safe Use for Health and Environment. Chemistry for Agriculture, Czech-Pol Trade, Prague - Brussels, $5,698-703$.

Rosada J. \& Grzesiak J., 2007. Ocena dostępności metali ciężkich występujących w glebach zanieczyszczonych emisjami Huty Miedzi GŁOGÓW. Progress in Plant Protection/Postępy w Ochronie Roślin, 47, 4, 91-94.

Rosada J. \& Grzesiak P., 2009. Wpływ optymalizacji procesów produkcyjnych na stan środowiska objętego oddziaływaniem przemysłu. Chemik. Miesięcznik Naukowo-Techniczny, 62, 3, 95-99.

Rosada J., Grzesiak J. \& Schroeder G., 2005a. Zagospodarowanie terenów rolniczych objętych oddziaływaniem hutnictwa metali nieżelaznych. [in:] Schroeder G. (red.), Chemiczne aspekty badań środowiska. T. 3, Uniwersytet im. Adama Mickiewicza, Poznań, 67-81.

Rosada J., Grzesiak J., Grzesiak P., Schroeder G., Orlicka A., Ratajczak J \& Rissmann I., 2005b. The Application of AAS and ICP Techniques for the Speciation of Trace Metals Insulated by Sequential Chemical Extraction. [in:] Górecki H., Dobrzański Z. \& Kafarski P. (eds), Development in Production and Use of New Agrochemicals, Chemistry for Agriculture, Czech-Pol Trade, Prague Brussels, 6, 464-477.

Rosada J., Grzesiak J., Schroeder G., 2005c. Agricultural Reclamation of Soils Contaminated by Heavy Metals Coming from Industrial Emission. [in:] Górecki H., Dobrzański Z. \& Kafarski P. (eds), Development in Production and Use of New Agrochemicals, Chemistry for Agriculture, Czech-Pol Trade, Prague - Brussels, 6, 869-872.

Ross S.M., 1994. Toxic metals in soil-plant system. John Wiley and Sons, London.

Rozporzadzenie Ministra Środowiska z dnia 9 września 2002 r. $w$ sprawie standardów jakości gleby oraz standardów jakości ziemi. Dz. U. 2002 nr 165, poz. 1359.

Spychalski W. \& Rosada J., 2004. Copper and Lead Fractions in Soils from the Emission Zone of the Copper Smelter GŁOGÓW. [in:] Górecki H., Dobrzański Z. \& Kafarski P. (eds), New Agrochemicals and Their Safe Use for Health and Environment, Chemistry for Agriculture, Czech-Pol Trade, Prague - Brussels, 5, 332-338.

Spychalski W. \& Rosada J., 2005. Zinc in Soils from the Emission Zone of the Copper Smelter GŁOGÓW and their Speciation by Sequential Extraction. [in:] Górecki H., Dobrzański Z. \& Kafarski P. (eds), Development in Production and Use of New Agrochemicals, Chemistry for Agriculture, Czech-Pol Trade, Prague - Brussels, 6, 484-489.

Spychalski W., Drzymała S. \& Rosada J., 2007. Exchangeable forms of $\mathrm{Cu}, \mathrm{Zn}$ and $\mathrm{Pb}$ in some soils subjected to the Copper Smelter GŁOGÓW activity. [in:] Górecki H., Dobrzański Z. \& Kafarski P. (eds), Chemicals in Agriculture and Environment, Chemistry for Agriculture, Czech-Pol Trade, Prague - Brussels, 8, 238-241.

Zeien H. \& Brümmer G.W., 1989. Chemische Extraktionen zur Bestimmung von Schwermetallbindungsformen in Boden. Mitteilungen der Deutschen Bodenkundlichen Gesellschaft, 59, 1, 505-510.

Zeien H. \& Brümmer G.W., 1991. Ermittlung der Mobilitat und Bindungsformen von Schwermetallen in Boden mittels Sequentieller Extraktionen. Mitteilungen der Deutschen Bodenkundlichen Gesellschaft, 66, 1, 439-442. 